PART 3

Economywide Perspectives 



\title{
NONFARM INCOME AND RURAL LABOR MARKETS
}

\author{
Fantu Bachewe, Guush Berhane, Bart Minten, \\ and Alemayehu Seyoum Taffesse
}

\section{Introduction}

Stimulating the off-farm economy in rural areas of developing economies is considered an important step toward structural transformation of such economies. In particular, the development of well-functioning rural labor markets is increasingly seen as crucial for economic growth and for the creation of livelihood opportunities for young people (for example, Fox et al. 2013). It is therefore important to understand how the off-farm sector and labor markets operate and to what extent their transforming influence is being felt. Moreover, rural wage increases are strongly linked with poverty reduction, since the majority of the population who are poor reside in rural areas and regularly depend on such wages for their livelihood (Ravallion 2000; Lanjouw and Lanjouw 2001).

We examine this issue in Ethiopia where the economy is changing fast. Having started from a low base, the Ethiopian economy still remains dominated by the agricultural sector, and the majority of the population still makes a living in this sector. While rapid transformation has occurred in agriculture (Chapter 3; Bachewe et al. 2015; World Bank 2015a), the implications of these changes on the rural off-farm economy are unclear. It has been shown in other settings that changes in off-farm income increasingly become important in rural areas when agriculture grows because of multiplier effects due to increased local spending by farmers (Haggblade, Hazell, and Reardon 2007).

This chapter provides new insights on the off-farm sector and labor markets in rural Ethiopia using recent large-scale datasets. While researchers have explored this issue in the past, the studies were based on relatively small surveys (Holden, Shiferaw, and Pender 2004; Dercon and Krishnan 1996; Block and Webb 2001). In particular, this chapter addresses the following four research questions: First, what is the importance of the off-farm sector in rural Ethiopia, and within the off-farm sector in particular, how important are labor markets? Second, what are the factors associated with rural income 
diversification? Third, are rural wages changing over time? Fourth, what are the drivers and the implications of these changes?

We define off-farm income as income generated from noncrop and nonlivestock production activities, or it is the sum of enterprise, agricultural wage, and nonagricultural wage incomes. Off-farm income makes up 18 percent of total rural household income in high-potential agricultural areas of the country. Agricultural and nonagricultural wage income accounted for 7 percent and 3 percent, respectively, of total household income, while enterprise income accounted for 8 percent. In these rural areas wage income is as important as livestock income, the latter accounting for 10.7 percent of household income. Hired labor is especially prevalent during specific periods of activity in the year-that is, during plowing, weeding, and harvesting. We find that off-farm income is more important in these high-potential agricultural areas than in other rural areas and that rural wages, driven by agricultural growth, are on the rise. These developments have important implications on poverty and on agricultural production practices. In particular, they affect incentives for the adoption of labor-saving technologies, such as herbicides and mechanization, as well as improve access to income in the lean period of the year when household food stocks may be depleted, possibly leading to improved agricultural productivity in the main season.

The chapter is organized as follows. First, we briefly describe the datasets used. Next we deal with the four research questions posed, analyzing rural off-farm income, looking specifically at agricultural hired labor use and agricultural wages and their associated factors, and studying trends in rural wages between 2004 and 2018 in Ethiopia. The results of our analyses on the drivers of change of real rural wages as well as the implications of these changes are discussed before our conclusion.

\section{Data}

For the descriptive and econometric analyses, we mainly use two data sources, complemented by a number of other datasets. First, we use price data collected by the Central Statistical Agency of Ethiopia (Ethiopia, CSA 2018a). CSA has been collecting monthly retail price data and data on prevailing wages since 1996 from about 120 markets, which were sampled to represent almost all administrative zones of the country. ${ }^{1}$ From this dataset we use nominal wages

1 CSA datasets leave out three of the five zones of Afar and six of the nine zones in Somali regions. 
of casual laborers and prices of a number of consumer food and nonfood items. We compute real wages using the Regional General Price Index data from CSA (Ethiopia, CSA 2018b) as well as a Poor-Persons' General Prices index that we created. The latter index is constructed using retail prices for 26 food and nonfood categories (334 items) coupled with data from CSA's Household, Income, Consumption, and Expenditure Survey (HICES) dataset of 2004/2005 (Ethiopia, CSA 2007), which provides information on the expenditure shares of the 26 food and non-food categories (Headey et al. 2012). We define "the poor" as the bottom two quintiles of households based on their aggregate expenditure.

Second, we analyze data collected through the Agricultural Growth Program of Ethiopia (AGP) baseline survey. This dataset was collected in four regions of the country: Tigray, Amhara, Oromia, and Southern Nations, Nationalities, and Peoples (SNNP). The survey was conducted in May 2011 and covered close to 8,000 households, who were sampled to represent more than 9 million households in 93 woredas or districts (Berhane et al. 2013). Information on agricultural production in the AGP baseline survey dataset pertains to the 2010/2011 main agricultural season.

The AGP baseline survey dataset is complemented with data from several other sources, including IFPRI's Ethiopia Strategy Support Program (ESSP) Teff Producers dataset; the ESSP Coffee Producers dataset; the Feed the Future $(\mathrm{FtF})$ midline impact evaluation survey; and from the Ethiopia Rural Socioeconomic Survey (ERSS). The Teff Producer dataset was collected in 2012 from 1,200 households in five major commercial teff-producing administrative zones of Amhara and Oromia regions. The Coffee Producer dataset, which includes about 1,600 households in five major coffee-producing areas of Oromia and SNNP, was collected in 2014. The FtF impact evaluation dataset, collected in 2015, and the ERSS dataset, collected in 2014, are two large-scale datasets that are used to provide additional insight into the importance of offfarm income in rural areas. We also use the World Development Indicators data (World Bank 2014) on real national GDP and value-added in the agriculture, manufacturing, and services sectors in our analyses of the drivers of rural wages. ${ }^{2}$ Similarly, we use Zonal Poverty Head Count Index data obtained from Hill and Tsehaye (2018) in our investigation of the welfare implications of real wages.

In all of the surveys considered, data were gathered at the household level through comprehensive survey instruments on crop production and sales for a complete agricultural year, which includes two cropping seasons (meher and

2 For exact definitions, see World Bank (2014). 
belg); on livestock production and sales; on agricultural and nonagricultural wage income; and on enterprise income for the 12 months preceding the survey period. While in some of the surveys, information on rental income and income transfers was collected, these data were not used, as these types of income constitute a relatively small share of total income and were not collected in all surveys. Therefore, for the purpose of this study, total household income is defined as the sum of net crop, livestock, and enterprise income, plus total wages earned from agricultural and nonagricultural labor.

Crop income is computed as the total value of crop output less the variable costs of production. Variable costs include money spent to purchase inputs such as fertilizer and improved seeds; to rent farm machinery or draft animals; to hire farm workers or other crop production-related costs. Similarly, livestock income is computed as the value of livestock sold or slaughtered and the value of livestock products, such as milk, honey, butter, and other products, less the variable costs of livestock production. Livestock production variable costs include wages paid to hire herding labor and costs incurred for veterinary and other related services. In each of the surveys price data collected at the community level are used to compute the value of crop and livestock production. Net enterprise income is computed as the difference between gross enterprise income for a business and total costs incurred for purposes of running the business. The definition of income for our purposes is different from monetary income, and in particular, incomes from crop and livestock production include both the value of home-consumed products and the value of sold quantities. Data on family labor used in enterprise and livestock production activities as well as services of nonpurchased inputs, such as own animals used for traction, were not collected. As a result, the values of these services are omitted from these calculations.

\section{Off-Farm Income in Rural Areas}

Here we investigate the importance of off-farm income in rural areas. The contribution of these income sources is described in both an international context and across regions in Ethiopia for different categories of households. We also present the results of our analyses of factors that are associated with participation in different income-generation activities.

\section{Off-Farm Income in Ethiopia}

Table 11.1 summarizes the data from the AGP baseline survey on the proportion of households with members employed in off-farm (agricultural and 
TABLE 11.1 Importance of off-farm income in rural areas (\%)

\begin{tabular}{lcrrrr}
\hline Income source & All regions & Tigray & Amhara & Oromia & SNNP \\
\hline Contribution of source to total income & & & & & \\
Crop & 71.4 & 59.8 & 69.6 & 72.2 & 73.3 \\
Livestock & 10.7 & 13.7 & 13.6 & 10.1 & 8.3 \\
Agricultural wage income & 6.6 & 7.8 & 9.1 & 5.9 & 5.1 \\
Nonagricultural wage income & 3.1 & 9.4 & 2.4 & 3.5 & 2.5 \\
Enterprise income & 8.1 & 9.3 & 5.3 & 8.3 & 10.9 \\
Households earning some income by type & & & & & \\
Crop income & 94.1 & 87.1 & 93.6 & 94.2 & 95.5 \\
Livestock income & 60.2 & 63.1 & 74.4 & 57.5 & 48.9 \\
Agricultural wage income & 21.4 & 16.3 & 29.0 & 20.2 & 15.9 \\
Nonagricultural wage income & 8.1 & 21.5 & 6.9 & 8.6 & 7.0 \\
Enterprise income & 25.4 & 20.2 & 18.0 & 28.8 & 28.1 \\
\hline
\end{tabular}

Source: Authors' computation using the Agricultural Growth Program of Ethiopia baseline survey data (2011).

Note: SNNP = Southern Nations, Nationalities, and Peoples.

nonagricultural wage labor and enterprise) activities and those engaged in crop and livestock production. The table also summarizes the contribution of each source to total household income. ${ }^{3}$

Several interesting findings are seen. First, the share of off-farm income is relatively low compared to shares observed in other settings (Reardon et al. 2006), and off-farm income is significantly related to the agricultural sector. Crop income makes up 71 percent of total household income. Wage income makes up 10 percent of total income, which is about the same share that households derive from livestock and livestock products. Enterprise income accounts for 8 percent of household income. If we divide incomes between agricultural and nonagricultural sources, however, only 11 percent of total household income is not related to agriculture-nonagricultural wage income accounts for only 3 percent of total household income.

Second, examining the share of households that obtain some income from each source, the number engaged in crop or livestock production is high, 94 percent and 60 percent, respectively. About 21 percent of the rural

3 In this chapter we focus on agricultural wage labor, which we view as distinct from other rural wage labor and business activities, thereby eliminating discrepancies that may arise due to differences in definitions of rural and agricultural. 
households earned income from agricultural wage labor, 25 percent were engaged in business enterprises, and 8 percent in nonagricultural wage labor.

Third, we see relatively little variation across different regions. Crop income is relatively more important in Amhara, Oromia, and SNNP regions, at 70,72 , and 73 percent, respectively, compared to Tigray (60 percent). Rural households in Tigray are somewhat more diversified with respect to income sources. Agricultural wage income as a share of total income is highest in the Amhara region (9 percent), possibly linked to seasonal migration to areas that produce cash crops, such as sesame.

To see how the results on income sources from the AGP survey compare to other recent large-scale datasets in the country, we examine information on income sources for rural households in the FtF and ERSS datasets (Table 11.2). Overall, we note the same orders of magnitude by income source: crop income makes up 80 percent and 71 percent of total household income in the FtF and ERSS dataset, respectively. However, in both cases, livestock income is evaluated to be more important than was observed in the AGP dataset, accounting for 11 percent and 20 percent of total income in the $\mathrm{FtF}$ and ERSS datasets, respectively. Off-farm income accounts for 7 percent and 9 percent, respectively, which is significantly smaller than in the AGP dataset (18 percent). Overall, these results confirm that the off-farm economy is small in rural Ethiopia. We use the Feed the Future impact evaluation survey datasets collected in 2015 and 2018 (as consistent income data were collected in both surveys) to see whether there were changes in the importance of off-farm income during that period. This analysis indicates that changes were relatively small: the importance of crop income in total household income declined by 4 percent, while livestock and transfer incomes increased by 1 percent and 3 percent, respectively, during that period.

We explore the factors associated with the importance of off-farm income using simple graphs and a regression analysis. First, we look at how the share of income sources varies by income level. To do so, we divide all households into five income quintiles and calculate shares of total income by income source for each (Figure 11.1).

Income from crop production contributes the lowest (64 percent) for households in the poorest income quintile (quintile 1 in Figure 11.1), and the contribution increases with total income. The contribution of livestock and nonagricultural wage income is higher in the bottom two income quintiles and declines with increases in total income. Agricultural wage income also contributes the highest in the lowest income quintile, while its contribution declines with increases in total income. Finally, enterprise income is more 
TABLE 11.2 Importance of off-farm income in rural areas, alternative estimates (\%)

\begin{tabular}{lcccrrrr}
\hline $\begin{array}{l}\text { Contribution of source } \\
\text { to total income }\end{array}$ & $\begin{array}{c}\text { Four AGP } \\
\text { regions }\end{array}$ & $\begin{array}{c}\text { Five regions } \\
\text { (including } \\
\text { Somali) }\end{array}$ & Tigray & Amhara & Oromia & SNNP & Somali \\
\hline Feed the Future (FtF) dataset & & & & & & & \\
Crop & 82.0 & 80.4 & 74.6 & 82.1 & 82.1 & 84.4 & 28.3 \\
Livestock & 11.3 & 12.7 & 19.1 & 12.0 & 11.3 & 7.2 & 61.2 \\
Agricultural wage & 1.5 & 1.5 & 1.3 & 1.7 & 1.7 & 1.0 & 0.8 \\
Nonagricultural wage & 1.6 & 1.6 & 1.5 & 1.5 & 1.8 & 1.4 & 3.7 \\
Enterprise & 3.7 & 3.8 & 3.6 & 2.7 & 3.2 & 5.9 & 6.0 \\
\hline & & All of Ethiopia, & & & & & \\
Contribution of source & Four AGP & excluding & & & & & All other \\
to total income & regions & Addis Ababa & Tigray & Amhara & Oromia & SNNP & regions \\
\hline Ethiopia Rural Socioeconomic Survey (ERSS) dataset & & & & & \\
Crop & 71.3 & 69.0 & 65.0 & 69.7 & 71.7 & 74.4 & 31.6 \\
Livestock & 19.6 & 21.1 & 22.2 & 20.9 & 19.4 & 17.3 & 45.9 \\
Casual labor & 2.0 & 2.0 & 3.3 & 1.9 & 1.8 & 2.1 & 2.5 \\
Salaried workers & 3.6 & 4.1 & 5.6 & 3.4 & 4.1 & 2.5 & 11.2 \\
Enterprise & 3.5 & 3.8 & 4.0 & 4.0 & 2.9 & 3.8 & 8.8 \\
\hline
\end{tabular}

Source: Authors' computation using the FTF (2013) and the Ethiopia Rural Socioeconomic Survey (ERSS) datasets. Note: AGP = Agricultural Growth Program of Ethiopia; SNNP = Southern Nations, Nationalities, and Peoples.

FIGURE 11.1 Contribution of different income sources to overall income in Ethiopia, by income quintile

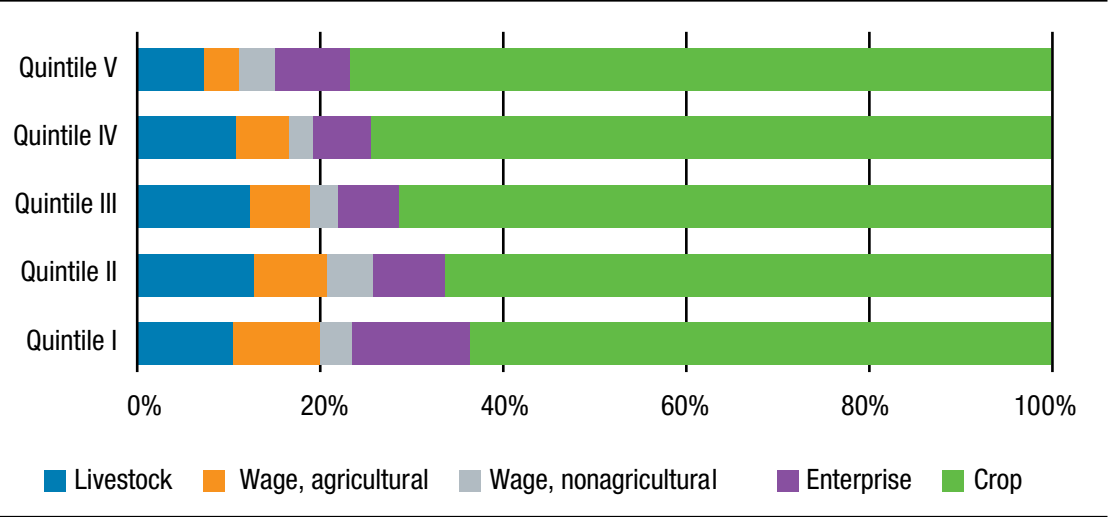

Source: Authors' computation using the 2011 AGP baseline survey data (Berhane et al. 2013). 
important in the lowest and highest income quintiles. The higher contribution of enterprise income in the lowest income quintile may appear to contradict the assumption that establishing businesses requires considerable initial investments. However, the businesses in which households within the highest and lowest income quintiles are engaged partly explains the apparent contradiction. For instance, brewing and selling local liquor and ale, which require relatively lower initial investments, are the two most important business activities in the lowest income quintile, while trading activities in grain and livestock are important for households in the highest income quintile. Overall, the off-farm sector is more important for the poor than for the rich, suggesting that push factors might still be relatively more important in rural areas for engagement by households in the rural off-farm income sector than are pull factors (Reardon et al. 2006; USAID 2011).

Second, we consider the contribution of income sources across land endowments as an alternative measure of wealth. Similar to the previous exercise, we look at the share of income sources for five quintiles of landownership, ranked from poor to rich. Figure 11.2 shows that the share of crop and livestock income significantly increases with land endowment. The share of income from the three off-farm income sources (agricultural wage, nonagricultural wage, and enterprise income) generally declines with land size. In particular, the contribution of each of the three income sources is nearly twice as high for households in the lowest land quintile (quintile 1) relative to those in the highest quintile. When we look at absolute levels, agricultural wage income of households in land quintile 1 and quintile 2 are higher than in both quintile 4 and quintile 5. The same holds for nonagricultural wage income of quintile 1 households. Enterprise income increases with land size, except that enterprise income of quintile 1 households is 37 percent higher than quintile 2 households. Crop and livestock income increase linearly with land size.

Third, we look at female- and youth-headed households (under 35 years of age). ${ }^{4}$ Table 11.3 shows the contribution of different sources of income to the overall income of households with heads in four gender-age categories. Offfarm income sources are relatively more important for youth-headed households. Off-farm income makes up 21 percent and 23 percent of total income for male-youth- and female-youth-headed households, respectively. This compares to 15 percent and 17 percent of male-mature- and female-matureheaded households, respectively. The younger households might have to rely

4 As these households were an explicit target of the AGP, they were oversampled to detect impact of the program on these particular households. 
FIGURE 11.2 Contribution of different income sources to overall income in Ethiopia, by land endowment quintile

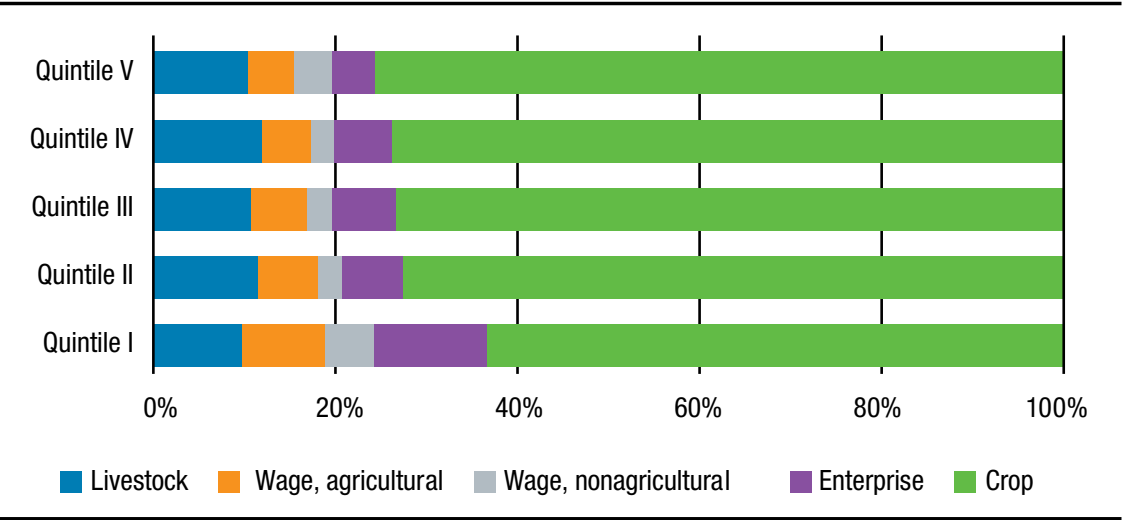

Source: Authors' computation using the 2011 AGP baseline survey data (Berhane et al. 2013).

TABLE 11.3 Importance of wage income in rural areas in Ethiopia, by gender and age of household heads (\%)

\begin{tabular}{lrrrr}
\hline Income source & $\begin{array}{c}\text { Male- } \\
\text { youth }\end{array}$ & $\begin{array}{c}\text { Male- } \\
\text { mature }\end{array}$ & $\begin{array}{c}\text { Female- } \\
\text { youth }\end{array}$ & $\begin{array}{c}\text { Female- } \\
\text { mature }\end{array}$ \\
\hline Contribution of source to total income & & & & \\
Crop & 68.0 & 74.3 & 65.0 & 72.9 \\
Livestock & 10.7 & 11.0 & 12.2 & 9.7 \\
Agricultural wage income & 7.4 & 5.4 & 9.9 & 6.9 \\
Nonagricultural wage income & 3.5 & 2.8 & 3.2 & 3.1 \\
Enterprise income & 10.4 & 6.6 & 9.7 & 7.3 \\
Households earning some income by type & & & & \\
Crop income & 93.6 & 96.0 & 88.6 & 93.2 \\
Livestock income & 61.2 & 62.6 & 60.6 & 54.2 \\
Agricultural wage income & 24.1 & 20.3 & 21.5 & 19.7 \\
Nonagricultural wage income & 9.5 & 8.1 & 6.7 & 6.7 \\
Enterprise income & 32.0 & 21.7 & 27.7 & 22.2 \\
\hline
\end{tabular}

Source: Authors' computation using the 2011 AGP baseline survey data (Berhane et al. 2013). 
more on off-farm sources of income as they often own less land than the more established households (Headey et al. 2012). The enterprise income and agricultural wage labor income especially are relatively important for youthheaded households. Notably, the female-headed households overall rely more on off-farm income than do male-headed households.

Fourth, Table 11.4 indicates the different types of enterprises that rural households are involved in. We see significant differences by income quintile. Selling homemade local liquor, producing handicrafts, trade in crop outputs, selling local ale, and selling prepared food items are important for households in the lowest income quintile in the order given. A higher proportion of households in the highest income quintile are engaged in selling crop outputs, livestock and livestock products, local liquor, retail nonagricultural items, and handicrafts. Several of the activities that a larger proportion of households in the highest income quintile are engaged in, such as trade in grains and livestock and livestock products, require substantial investment, while the production and sales of local liquor, handicrafts, and food items, enterprises in which poorer households are engaged, require a relatively lower investment.

Finally, we look at the factors associated with involvement in off-farm income using a regression framework. Using Escobal's (2001) methodology, we run Tobit models that show the factors associated with diversification (defined as the share of income in percent from sources other than crop agriculture and livestock production). In particular, we look at agricultural and nonagricultural wage income and enterprise income. We conduct the analysis using as dependent variable an aggregate measure of income diversification that accounts for both the number and share of income sources: the Herfindahl Diversification Index (HDI), which is defined as:

$$
H D I_{i}=1-H I_{i}=1-\sum_{j}^{K}\left(\frac{\mathrm{Y}_{\mathrm{ij}}}{\sum_{\mathrm{j}=1}^{\mathrm{K}} Y_{i j}}\right)^{2}
$$

in which the term in parentheses is the contribution of income from source $\mathrm{j}\left(Y_{i j}\right)$ to total income $\left(\sum_{\mathrm{j}=1}^{\mathrm{K}} Y_{i j}\right)$. ${ }^{5}$ Results of these analyses are provided in Table 11.5.

First, the results show a strong association between income sources and the age and education of the head of household. Crop and livestock income are positively associated with the age of the household head, while agricultural wage and enterprise income are negatively related to age. Diversification

5 HDI ranges between 0 and $1 . \mathrm{HDI}=0$ for households that generate their entire income from only one source, and it increases with number and balancedness in share of income sources. 
TABLE 11.4 Percentage of households engaged in different business enterprises in Ethiopia, by income quintile (\%)

\begin{tabular}{|c|c|c|c|c|c|c|}
\hline Business activity & $\begin{array}{c}\text { Quintile } \\
1\end{array}$ & $\begin{array}{l}\text { Quintile } \\
\quad 2\end{array}$ & $\begin{array}{l}\text { Quintile } \\
3\end{array}$ & $\begin{array}{c}\text { Quintile } \\
4\end{array}$ & $\begin{array}{c}\text { Quintile } \\
5\end{array}$ & All \\
\hline Weaving/spinning & 5.6 & 9.0 & 1.8 & 0.5 & 1.6 & 3.2 \\
\hline Milling & 0.1 & 1.2 & 0.1 & 0.2 & 3.3 & 1.2 \\
\hline Handicrafts & 16.5 & 16.2 & 17.2 & 14.2 & 6.6 & 13.5 \\
\hline Trade in grains and other crop items & 13.3 & 12.2 & 11.9 & 17.1 & 22.3 & 16.0 \\
\hline Trade in livestock and livestock products & 6.4 & 3.7 & 10.3 & 13.1 & 15.8 & 10.8 \\
\hline Trade in nonagricultural merchandise & 4.6 & 9.4 & 9.2 & 10.1 & 12.4 & 9.8 \\
\hline Transport (by pack animal) & 0.0 & 0.1 & 0.2 & 0.2 & 2.6 & 0.8 \\
\hline Tella (local ale) & 11.8 & 4.6 & 4.4 & 4.1 & 4.5 & 5.1 \\
\hline Araqi (local liquor) & 19.7 & 18.3 & 22.0 & 21.3 & 15.1 & 19.1 \\
\hline Prepared food (bread/enjera) & 6.8 & 2.5 & 4.9 & 0.9 & 2.8 & 3.2 \\
\hline Other businesses & 15.2 & 22.8 & 17.8 & 18.3 & 13.0 & 17.3 \\
\hline Total & 100.0 & 100.0 & 100.0 & 100.0 & 100.0 & 100.0 \\
\hline
\end{tabular}

Source: Authors' computation using the 2011 AGP baseline survey data (Berhane et al. 2013).

(HDI) is negatively associated with the age of the household head. This suggests that households with younger heads are more likely to rely on off-farm income sources to assure their livelihoods. Diversification is also positively related to the education of the household head and to the number of members in the household. Enterprise and nonagricultural wage income, which require more skills than agricultural labor, are positively associated with the heads' education, while the latter is negatively associated with self-employed and hired agricultural labor income.

Second, there is a strong gender component to off-farm income. The proportion of females among total household members of working age (1665 years) is negatively associated with both categories of hired labor. This could be because female members of households in rural areas spend more time on household chores and have limited time to engage in hired labor. This is in addition to the fact that females, particularly younger girls, are generally discouraged from working as hired labor because in many communities it is socially unacceptable for these young girls to work outside of the household. The number of females engaged in hired labor is about half $(56$ percent) the number of males.

Third, a greater quantity and better quality of agricultural assets lead to less diversification. As implied in the discussion above, total household land 
TABLE 11.5 Factors associated with the contribution of farming, business enterprise, and wage employment to total income in Ethiopia

\begin{tabular}{|c|c|c|c|c|c|}
\hline Variables & $\begin{array}{c}\text { Self- } \\
\text { employment, } \\
\text { agriculture } \\
\text { (crop + } \\
\text { livestock) }\end{array}$ & $\begin{array}{c}\text { Self- } \\
\text { employment, } \\
\text { nonagriculture } \\
\text { (enterprise) }\end{array}$ & $\begin{array}{c}\text { Wage } \\
\text { employment, } \\
\text { agriculture }\end{array}$ & $\begin{array}{c}\text { Wage } \\
\text { employment, } \\
\text { nonagriculture }\end{array}$ & $\begin{array}{l}\text { Herfindahl } \\
\text { Diversification } \\
\text { Index }\end{array}$ \\
\hline \multicolumn{6}{|l|}{ Household variables } \\
\hline $\begin{array}{l}\text { Gender of household } \\
\text { head ( }=1 \text { if male) }\end{array}$ & 0.932 & -3.439 & 1.914 & 2.434 & $0.028^{*}$ \\
\hline $\begin{array}{l}\text { Age of household head } \\
\text { (years) }\end{array}$ & $0.407^{\star \star \star}$ & $-0.543^{\star \star \star}$ & $-0.378^{\star \star \star}$ & -0.110 & $-0.003^{\star \star \star}$ \\
\hline Education of head & $-3.002^{\star \star \star}$ & $5.742^{\star \star \star}$ & $-2.283^{\star \star}$ & $5.276^{\star \star \star}$ & $0.018^{\star \star \star}$ \\
\hline Household size & -0.335 & 0.122 & 0.435 & $2.113^{\star \star}$ & $0.011^{\star \star \star}$ \\
\hline $\begin{array}{l}\text { Proportion of females in } \\
\text { working age }\end{array}$ & 5.370 & 10.295 & $-16.570^{\star \star \star}$ & $-17.640^{\star}$ & -0.030 \\
\hline \multicolumn{6}{|l|}{ Farm characteristics } \\
\hline $\begin{array}{l}\text { Purchased at least one } \\
\text { input on credit }\end{array}$ & -0.239 & 0.268 & -3.561 & $7.820^{\star}$ & $0.026^{\star}$ \\
\hline $\begin{array}{l}\text { Total cultivated area } \\
\text { (hectares) }\end{array}$ & $4.149^{\star \star \star}$ & -0.426 & $-2.741^{\star \star}$ & $-7.684^{\star \star \star}$ & -0.011 \\
\hline $\begin{array}{l}\text { Total cultivated area- } \\
\text { squared }\end{array}$ & $-0.239^{\star \star \star}$ & 0.102 & 0.066 & $0.481^{\star \star \star}$ & 0.000 \\
\hline Land quality index & $1.138^{\star \star \star}$ & $-1.400^{\star \star \star}$ & -0.500 & -0.255 & $-0.006^{\star \star}$ \\
\hline Tropical livestock units & $2.161^{\star \star \star}$ & $-1.370^{\star \star \star}$ & $-1.951^{\star \star \star}$ & $-5.416^{\star \star \star}$ & $-0.012^{\star \star \star}$ \\
\hline
\end{tabular}

area is positively associated with agricultural income and negatively with agricultural and nonagricultural wage income. Higher land quality, computed from self-reported soil fertility and slope measures by the respondent, is positively associated with agricultural income and generally negatively associated with diversification. The number of tropical livestock units (livestock measured in camel units) is positively associated with agricultural income, while it is negatively related to the remaining income sources (wage and enterprise income) as well as to diversification.

Fourth, consistent with other settings and countries, proximity to cities is often an important factor associated with income diversification in rural Ethiopia (Deichmann, Shilpi, and Vakis 2009; Fafchamps and Shilpi 2005, 2003; Jacoby and Minten 2009). Diversification and enterprise income decline with distance from both the capital Addis Ababa and the nearest urban center of 50,000 or more inhabitants, while agricultural income increases with distance from urban centers. Agricultural and nonagricultural 


\begin{tabular}{|c|c|c|c|c|c|}
\hline Variables & $\begin{array}{l}\text { Self- } \\
\text { employment, } \\
\text { agriculture } \\
\text { (crop + } \\
\text { livestock) }\end{array}$ & $\begin{array}{c}\text { Self- } \\
\text { employment, } \\
\text { nonagriculture } \\
\text { (enterprise) }\end{array}$ & $\begin{array}{c}\text { Wage } \\
\text { employment, } \\
\text { agriculture }\end{array}$ & $\begin{array}{c}\text { Wage } \\
\text { employment, } \\
\text { nonagriculture }\end{array}$ & $\begin{array}{l}\text { Herfindahl } \\
\text { Diversification } \\
\text { Index }\end{array}$ \\
\hline \multicolumn{6}{|l|}{ Location } \\
\hline $\begin{array}{l}\text { Travel time to nearest } \\
50,000 \text { town (minutes) }\end{array}$ & $0.032^{\star \star \star}$ & $-0.018^{\star \star}$ & -0.006 & $-0.087^{\star \star \star}$ & $-0.000^{\star \star \star}$ \\
\hline $\begin{array}{l}\text { Distance from Addis Aba- } \\
\text { ba (hundred kilometers) }\end{array}$ & $1.524^{\star}$ & $-5.482^{\star \star \star}$ & $2.996^{\star \star \star}$ & $-6.132^{\star \star \star}$ & $-0.014^{\star \star}$ \\
\hline Total district population ${ }^{\mathrm{a}}$ & $0.024^{*}$ & $-0.048^{\star \star}$ & -0.003 & 0.046 & -0.000 \\
\hline $\begin{array}{l}\text { Zonal poverty head count } \\
\text { index }\end{array}$ & $-0.144^{\star \star}$ & $0.565^{\star \star \star}$ & $-0.283^{\star \star \star}$ & 0.016 & $0.001^{\star}$ \\
\hline Amhara & $18.840^{\star \star \star}$ & $-24.408^{\star \star \star}$ & $21.050^{\star \star \star}$ & $-73.010^{\star \star \star}$ & $-0.093^{\star \star \star}$ \\
\hline Oromia & $17.810^{\star \star \star}$ & $-8.727^{*}$ & $14.460^{\star \star \star}$ & $-68.950^{\star \star \star}$ & $-0.090^{\star \star \star}$ \\
\hline SNNP & $15.050^{\star \star \star *}$ & 1.749 & 3.295 & $-72.620^{\star \star \star}$ & $-0.086^{\star \star \star}$ \\
\hline Constant & $50.950^{\star \star \star *}$ & -13.316 & $-20.860^{\star *}$ & -1.588 & $0.195^{\star \star \star}$ \\
\hline Chi-squared & 389 & 314 & 154 & 464 & 318 \\
\hline Number of observations & \multicolumn{5}{|c|}{7,178} \\
\hline $\begin{array}{l}\text { Turning point for total } \\
\text { cultivated area }\end{array}$ & 8.692 & n.a. & n.a. & 7.981 & n.a. \\
\hline
\end{tabular}

Source: Authors' analysis using the 2011 AGP baseline survey data (Berhane et al. 2013) except as noted: a. Ethiopia, CSA (2014); b. Hill and Tsehaye (2014).

Note: SNNP = Southern Nations, Nationalities, and Peoples. Coefficients with superscripts ${ }^{\star \star \star}$, ${ }^{\star \star}$, and * are significant at 1 percent, 5 percent, and 10 percent levels, respectively. n.a. = not applicable.

wage employment are positively and negatively associated with distance from Addis Ababa. The size of the coefficients indicates that households located 100 kilometers from Addis Ababa have 11 percent less income from the nonagricultural sector $(5$ percent less from self-employment and 6 percent less from wages) than households living close to Addis Ababa. Finally, the Zonal level Poverty Head Count index is also positively related to diversification overall, suggesting again that push factors are important for household income diversification in rural Ethiopia.

\section{Off-Farm Income in Ethiopia in an International Context}

Comparing off-farm income patterns for rural households in Ethiopia with those in other countries provides a broader perspective. First, we compare the importance of the rural off-farm sector with other countries. Reardon et al. (2006) find that off-farm income made up 36 percent of total income in Africa, 50 percent in Asia, and 43 percent in Latin America (Figure 11.3). 
FIGURE 11.3 Off-farm income as share of total income in rural areas in Ethiopia, from local sources and from migration income (\%)

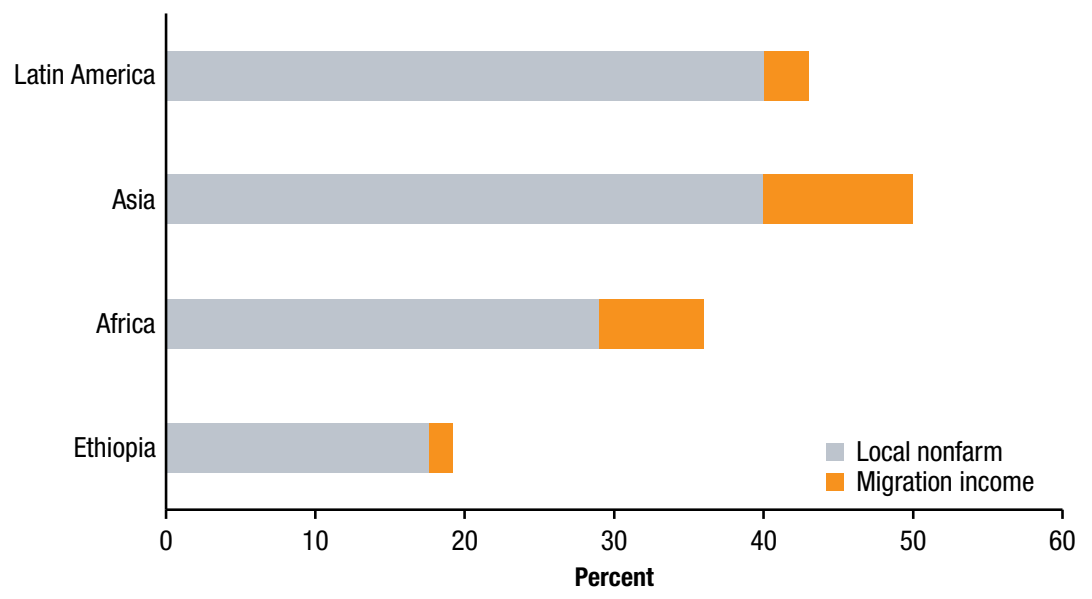

Source: Reardon et al. (2006), and for Ethiopia the migration income (transfer) and local nonfarm numbers are from ERSS and AGP baseline survey datasets, respectively.

They show that most off-farm income comes from local off-farm sources and less from wage income obtained through migration. In Ethiopia the off-farm sector accounts for 18 percent of total rural household income, which is significantly smaller than the African average. As shown in Figure 11.3 in more developed continents, the share of this off-farm sector is expected to increase with anticipated growth in Ethiopia's economy.

Second, we look at wage levels using the AGP data. The distribution of agricultural wages paid in US dollars (US\$) during the survey period are shown in Figure 11.4 (left). An average wage of agricultural workers in these high potential areas was 19.5 birr (US\$1.27) per day. Average wages of all rural workers, including nonagricultural labor, are slightly lower at 19 birr (US\$1.24) per day. Wage data from other countries, obtained from Wiggins and Keats (2014) and Zhang et al. (2014), are also shown in Figure 11.4 (right). Unfortunately, these data provide only an indication of wages paid in Asian countries, and data from the African continent are sparse. In any case, we find that wages in Ethiopia are significantly lower than in Asian countries for which data are available. It is estimated that agricultural wages in Ethiopia were only 57 percent, 44 percent, and 56 percent of the average agricultural wages paid in Nepal, Bangladesh, and Myanmar, respectively. 
FIGURE 11.4 Frequency distribution of agricultural wages in Ethiopia (left), and agricultural wages in Ethiopia compared to a number of other countries in US\$ per day (right)

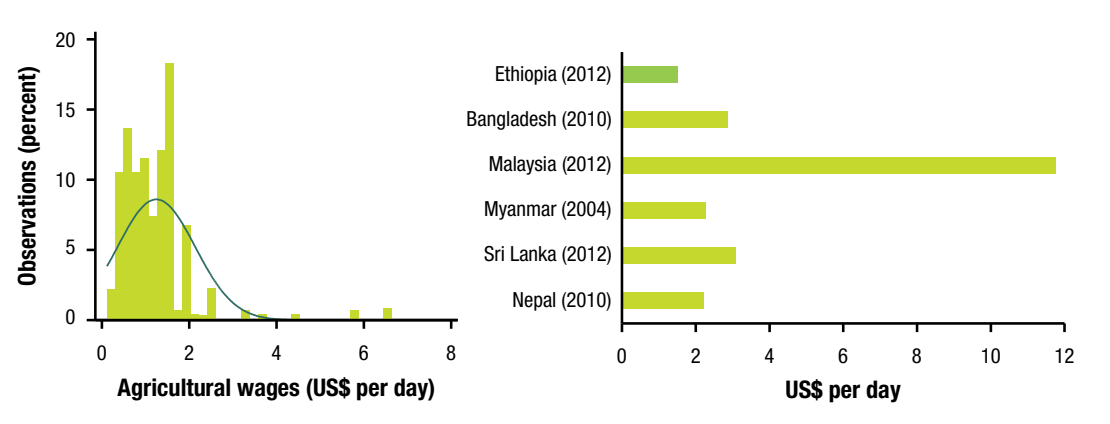

Source: Wiggins and Keats (2014); Zhang et al. (2014).

\section{Agricultural Wages and Agricultural Labor Market Use}

Here we investigate the contribution of hired-in labor in total agricultural labor; seasonality in agricultural labor use; and factors associated with agricultural wages. We study factors associated with participation in rural labor markets, particularly from the demand side.

\section{Agricultural Wage Labor}

Table 11.6 summarizes the share of crop-producing households that relied entirely on family or on hired-in labor, and those that used both family and hired-in labor. Three important observations can be made. First, family labor is by far the most important contributor to agricultural work-hired labor contributes only 7 percent to all agricultural work. Second, there is important regional heterogeneity in terms of the share of hired-in labor. The share of hired-in labor is highest in Tigray region, where it makes up 14 percent of total labor used in crop production, and lowest in Amhara, constituting only 4 percent. The low levels of hired-in labor in Amhara is surprising given the relatively larger importance of agricultural wage income in the region. This result possibly indicates the importance of seasonal migration in the region to work on commercial farms. Third, the proportion of farms that exclusively rely on hired-in labor is low at only 1 percent. The vast majority of households rely exclusively on family labor-more than three-quarters of these farms exclusively use family labor for crop production. Nearly 23 percent of households used a combination of family and hired-in labor. We disaggregate the 
TABLE 11.6 Share of hired-in labor and households using hired-in labor for crop production in Ethiopia (\%)

\begin{tabular}{lccccccc}
\hline & \multicolumn{2}{c}{ Share of total labor use } & & \multicolumn{3}{c}{ Proportion of households using } \\
\cline { 2 - 3 } Region & $\begin{array}{c}\text { Family } \\
\text { labor }\end{array}$ & $\begin{array}{c}\text { Hired-in } \\
\text { labor }\end{array}$ & & $\begin{array}{c}\text { Only family } \\
\text { labor }\end{array}$ & $\begin{array}{c}\text { Only hired } \\
\text { labor }\end{array}$ & $\begin{array}{c}\text { Family and } \\
\text { hired labor }\end{array}$ \\
\hline All regions & 93.0 & 7.0 & & 76.1 & 1.1 & 22.8 \\
Tigray & 86.1 & 13.9 & & 62.2 & 3.5 & 34.3 \\
Amhara & 96.1 & 3.9 & & 81.4 & 0.3 & 18.3 \\
Oromia & 93.0 & 7.0 & & 72.5 & 0.4 & 27.1 \\
SNNP & 90.6 & 9.4 & & 78.8 & 3.0 & 18.2 \\
\hline
\end{tabular}

Source: Authors' computation using the 2011 AGP baseline survey dataset (Berhane et al. 2013). Note: SNNP = Southern Nations, Nationalities, and Peoples.

data by the type of crop cultivated. The results reveal surprisingly little differences in the share of hired-in labor use across crops, ranging from 4.5 percent of total labor used for pulses to 7.5 percent for oilseeds.

We triangulate this issue using the Teff Producer and Coffee Producer surveys. These surveys hold more detailed information on the type of labor use for the different agricultural activities during the year as well as information on the importance of exchange labor that is prevalent in some regions. The latter information was not collected in the AGP surveys. The results are presented in Table 11.7. Note that the larger farms are oversampled in both these surveys to ensure that a representative picture for the total quantity produced and commercialized would emerge.

Family labor accounted for 63 percent and 68 percent of all labor used in major teff- and coffee-producing areas, respectively. In addition, exchange labor or other forms of social labor accounted for 22 percent and 18 percent of the total labor used in the respective producing areas. The share of exchange labor is even more important than hired-in labor in these contexts, the latter standing at 14 percent. While exchange labor is invariably important, there are key variations in its use over space. Figure 11.5 depicts the information on the share of hired-in, family, and exchange labor by distance to Addis Ababa as measured in terms of the cost of transporting a quintal of grain to the capital city. The figure shows that households in areas closer to Addis Ababa rely more on hired-in labor than they do on exchange labor, while the reverse holds in areas farther away from Addis Ababa. This figure suggests that households 
TABLE 11.7 Share of labor arrangements for different activities in Ethiopia (\%)

\begin{tabular}{|c|c|c|c|c|c|c|}
\hline \multirow[b]{2}{*}{ Practice } & \multicolumn{3}{|c|}{ Teff } & \multicolumn{3}{|c|}{ Coffee } \\
\hline & Family & Hired & Exchange & Family & Hired & Exchange \\
\hline Tree management & n.a. & n.a. & n.a. & 88 & 4 & 9 \\
\hline Mulching & n.a. & n.a. & n.a. & 83 & 7 & 10 \\
\hline Tilling & 85 & 7 & 8 & 63 & 12 & 25 \\
\hline Manure and organic input use & 93 & 4 & 3 & 92 & 3 & 5 \\
\hline Sowing and fertilizer use & 86 & 6 & 7 & 85 & 6 & 9 \\
\hline Weeding & 73 & 10 & 16 & 70 & 11 & 19 \\
\hline Herbicide and pesticide application & 76 & 23 & 1 & n.a. & n.a. & n.a. \\
\hline Harvesting & 41 & 32 & 27 & 68 & 19 & 13 \\
\hline Postharvesting activities & 69 & 7 & 24 & 98 & 1 & 1 \\
\hline Threshing and winnowing & 57 & 11 & 32 & n.a. & n.a. & n.a. \\
\hline Total & 63 & 14 & 22 & 68 & 14 & 18 \\
\hline
\end{tabular}

Source: Authors' computation using IFPRI and EDRI $(2019,2020)$.

Note: n.a. $=$ not applicable.

FIGURE 11.5 Labor arrangements and remoteness in Ethiopia

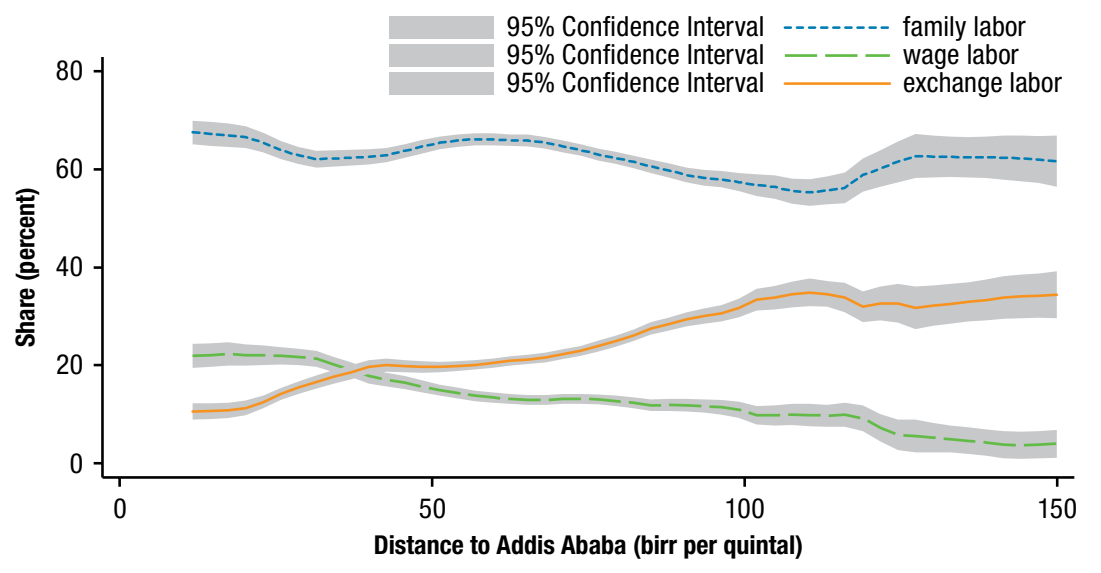

Source: Authors' computation using IFPRI and EDRI $(2019,2020)$. 
shift to wage and market labor arrangements in more commercialized and better-connected areas. ${ }^{6}$

Table 11.7 shows that there also exist significant seasonal variations in hired-in labor use. Hired-in labor is much more important during harvest periods in both major teff- and coffee-producing areas. Hired-in labor was also relatively important during the tilling and weeding periods. Of the total labor used in teff and coffee harvesting, 32 percent and 19 percent was accounted for by hired-in labor, respectively.

\section{Factors Associated with Agricultural Wages}

Next we investigate factors associated with wage levels and test if and to what extent agricultural workers' wages vary with type of agricultural work, worker characteristics, and locational factors. In the econometric analyses we use the AGP baseline survey dataset. We complement this data with an urban dummy variable constructed from CSA's woreda population predictions (Ethiopia, CSA 2014) and zonal poverty head count (HC) index data from Hill and Tsehaye (2018). ${ }^{7}$ The variables used in the regression analyses are defined and the results provided in Table 11.8 .

The results indicate that workers that hired-out labor for planting earn lower wages (13 percent lower) relative to those that worked on land preparation, which is the omitted category, while wages of laborers engaged in weeding and harvesting earned 12 percent and 17 percent more, ceteris paribus. Wages for livestock herding were not statistically different from land preparation. The results also indicate that male workers are paid 8 percent more than females, controlling for the type and location of the work. Moreover, wages decline with the age of the worker, possibly indicating that the productivity of older workers is presumed to be lower.

The results further indicate that wages increase with proximity to urban centers. A further 100 kilometers away from Addis Ababa reduces agricultural wages by 7 percent. Remoteness from the local market is also associated with the payment of lower wages, but these effects are small. Furthermore,

6 A similar picture shows up for a switch to land rental agreements from sharecropping as households live closer to Addis Ababa.

7 To address the endogeneity problem that could arise if the poverty HC index is endogenously determined with wages, we use the predicted value of the poverty $\mathrm{HC}$ index obtained from a first-stage regression of the latter variable on factors associated with poverty but not used in the second-stage analysis. The dependent variables used in the first stage (zonal level) regression are: household-level average values of cultivated area, value of crop and livestock outputs, and proportion of households that accessed credit to purchase inputs. We thank an anonymous reviewer for indicating this problem. 
TABLE 11.8 Region, activity, and gender factors associated with rural wages in Ethiopia

\begin{tabular}{lcc}
\hline $\begin{array}{l}\text { Dependent variable: log of agricultural wages (birr per day) } \\
\text { Variable }\end{array}$ & Coefficient & Standard Error \\
\hline Planting & $-0.120^{\star \star}$ & 0.048 \\
Weeding & $0.127^{\star \star \star}$ & 0.037 \\
Harvesting & $0.181^{\star \star \star}$ & 0.032 \\
Herding & -0.114 & 0.153 \\
Gender of worker (=1 if male) & $0.081^{\star \star \star}$ & 0.027 \\
Worker age (years) & $-0.002^{\star}$ & 0.001 \\
Distance to daily/periodic market (kilometers) & $-0.001^{\star \star \star}$ & 0.000 \\
Distance from Addis Ababa (hundred kilometers) & $-0.120^{\star \star \star}$ & 0.015 \\
Total district population & $0.002^{\star \star \star}$ & 0.000 \\
Zonal poverty head count index (predicted) & $-0.010^{\star \star \star}$ & 0.003 \\
Amhara & $-0.179^{\star \star \star}$ & 0.057 \\
Oromia & $-0.581^{\star \star \star}$ & 0.063 \\
SNNP & $-0.264^{\star \star \star}$ & 0.051 \\
Constant & $3.369^{\star \star \star}$ & 0.123 \\
\hline F-statistics & \multicolumn{2}{c}{28} \\
Number of observations & \multicolumn{2}{c}{2,365} \\
\hline
\end{tabular}

Source: Authors' analysis using the 2011 AGP baseline survey data (Berhane et al. 2013), Ethiopia, CSA (2014), and Hill and Tsehaye (2018). Coefficients with superscripts ${ }^{\star \star \star},{ }^{\star *}$, and ${ }^{*}$ are significant at 1 percent, 5 percent, and 10 percent levels, respectively.

Note: SNNP = Southern Nations, Nationalities, and Peoples.

agricultural wages decline with the Poverty Head Count index in the administrative zone, even after controlling for location differences, indicating the strong link of agricultural wage levels with poverty measures. This suggests that in areas where a higher proportion are poor, the resulting lower wages from a higher labor supply means that the poor might rely relatively more on these labor markets for their livelihoods. Region dummy variables used in the analysis imply that agricultural wages are relatively higher in Tigray.

\section{Factors Associated with Agricultural Labor Use}

We look at factors associated with hired-in agricultural labor use. For this, we use a Tobit model to investigate whether household and location-specific factors explain the proportion of hired-in labor out of total labor. Variables used in the regression analysis and results obtained are provided in Table 11.9.

The results in Table 11.9 indicate that household characteristics are important for decisions on labor markets. First, the share of hired-in labor 
TABLE 11.9 Factors associated with hired-in labor use (Tobit regression) in Ethiopia

Dependent variable: share of hired-in labor (\%)

Variables

Coefficient

Standard error

Household variables

Gender of household head ( $=1$ if male)

$-4.10$

2.624

Age of household head (years)

$-0.08$

0.062

Education of head

$4.60^{\star \star *}$

0.840

Dependency ratio

$0.15^{\star \star \star}$

0.041

Household size

$-3.57^{\star \star \star}$

0.490

Proportion of females in working age

$14.79^{\star \star \star}$

Farm characteristics

Total cultivated area (hectares)

$12.47^{\star \star \star}$

Total cultivated area-squared

$-0.70^{\star \star \star}$

0.100

Land quality index

$1.82^{\star \star \star}$

0.431

Tropical livestock units

$1.30^{\star \star \star}$

0.224

Household obtains production information

$5.01^{\star \star \star}$

Model farmer in last five years? (=1 if yes)

$7.01^{\text {** }}$

Visited by extension agent ( $=1$ if yes)

0.94

1.959

Location

Travel time to nearest 50,000 town (minutes)

$-0.02^{\star \star \star} \quad 0.006$

Distance from Addis Ababa (hundred kilometers)

$-4.14^{\star \star \star}$

Urban ( $=1$ if woreda population $\geq 50,000$ )

$73.03^{\star \star \star}$

12.680

Zonal poverty head count index

0.073

Amhara

$0.22^{\star \star \star}$

Oromia

$-30.29^{\star \star \star}$

3.746

SNNP

$-38.69^{\star \star \star}$

Constant

15.190

Chi-squared

$-105.30^{\star \star \star}$

Number of observations

Turning point for total cultivated area

8.891

Source: Authors' analysis using the 2011 AGP baseline survey data (Berhane et al. 2013), except those with superscripts a and b, which are from Ethiopia, CSA (2014) and Hill and Tsehaye (2018). Coefficients with superscripts ${ }^{\star \star \star}$, **, and * are significant at 1 percent, 5 percent, and 10 percent levels, respectively.

Note: SNNP = Southern Nations, Nationalities, and Peoples. "Tropical livestock units" normalizes the number of livestock a household owns in camel units. "Model farmer" takes a value of 1 if the household head was selected as a model farmer in the last five years. "Production information" takes a value of 1 if the head obtained production information from radio, newspaper, or information boards. "Extension" takes a value of 1 if the household was visited by extension agents at least once in the last 12 months. The "Land Quality index" is computed by multiplying perceived fertility (three categories) and slope (three categories) of each plot of land; whereby the index ranges from the poorest (1) to the best (9) land quality. Household-level land quality index is computed as a plot area weighted sum of land quality indexes of plots cultivated. 
decreases with the dependency ratio and vice versa for household size. As household size increases, there is more labor available and the likelihood of hiring in labor is therefore reduced. A higher share of elder and younger people-and therefore a higher dependency ratio—reduces labor supply, ceteris paribus, leading to more hiring-in of labor. The education levels of household heads also show a significant association with reliance on labor markets. More educated household heads are more likely to hire-in labor, since they are more likely to be engaged in alternative activities outside of their farms.

Second, farm characteristics also determine how households will participate in agricultural labor markets. The size of the farm is an important factor associated with labor market participation. The bigger the farm, the more likely the household will use hired-in labor. An increase in the size of the farm by one hectare leads to an increase of the share of expected hired-in labor by 12 percent. Households that cultivate better quality land are more likely to hire-in laborers, possibly to cultivate the better-quality land more intensively. Moreover, the proportion of hired-in labor increases with livestock ownership, probably from the need to use more labor to care for livestock as well as due to the wealth effect of owning a larger herd.

Third, we look at the effect of location variables. Holding other factors constant, farmers in zones with a higher incidence of poverty are more likely to hire agricultural workers, possibly because of the lower wage in such zones. The proportion of hired-in labor increases in urban areas and with proximity to Addis Ababa. The latter is consistent with better functioning labor markets in areas closer to large population centers, along with incentives for more intensive cultivation of land. Better functioning labor markets also imply employment opportunities, other than agricultural work. All regional dummies are significant and negative, which indicates that the proportion of hired-in labor is lower in Amhara, Oromia, and SNNP compared with Tigray.

\section{Rural Wages: Changes, Drivers, and Implications}

\section{Changes in Rural Wages}

Here we describe trends in real wages of unskilled or casual labor in both rural and urban areas. This is important for at least three reasons. First, since rural wages benchmark the wages paid in the manufacturing and service sectors, trends in rural-urban wage gaps over time will have important implications for Ethiopia's transformation from a largely agrarian toward a manufacturing-led 
economy. Second, rising wages have important implications on rural development and overall poverty reduction given the potential increase in the cost of food production and food prices resulting from rising wages. An important question is whether increases in wages in the future more than compensate for welfare losses due to subsequent food price increases. Third, changes in rural wages often trigger changes in farming systems by, for example, driving the introduction of labor-saving mechanization or bringing about changes in farm sizes, partly because the use of machinery reduces the advantage of small-scale farm operations in labor supervision (Otsuka, Liu, and Yamauchi 2014). In the case of Ethiopia, the latter depends on the extent to which land is consolidated and how this is facilitated in the future. To understand some of these issues, we use data on the daily wages of unskilled laborers collected by CSA on a monthly basis during the period July 2004 to September 2018. We return to each of these points below.

We discuss trends in wages expressed in US dollars (US\$) and in US Consumer Price Index (CPI) deflated real US dollars. However, this deflation method might be imperfect because of changes in the overvaluation of the birr-dollar exchange rate over time (World Bank 2014). We therefore also rely on other deflation methods. First, we use the regional General CPI (GCPI) from CSA (Ethiopia, CSA 2018b). Second, we use the Poor Persons' General CPI (PP-GCPI). The PP-GCPI is constructed using expenditure shares on 26 food and nonfood categories of households in the lowest two income quintiles, which we define as poor households, obtained from CSA (Ethiopia, CSA 2007) and retail prices for those items (Ethiopia, CSA 2018a; see Headey et al. 2012).

Figure 11.6 depicts the daily wages of casual laborers expressed in nominal US dollars and real US dollars. These figures are important as they show what international investors would pay to employ unskilled labor in the country. Therefore, they are indicators of the competitiveness of Ethiopia in labor-intensive industries. Figure 11.6 shows that wages of unskilled laborers increased dramatically during July 2004 through September 2018, with daily wages nearly quadrupling in the period considered. Specifically, wages expressed in US dollars and real US dollars per person per day, which averaged 0.86 and 0.92 in the third quarter of 2004, grew to 3.28 and 2.63 in the third quarter of 2018, respectively. Growth in the respective wages averaged 10 percent and 7.8 percent per year, or 0.8 percent and 0.6 percent per month. However, the growth was not consistent over this period, and there was a slight decline in wages between January 2009, September 2010, and 
FIGURE 11.6 Wages of unskilled laborers per day in Ethiopia in nominal US\$ and real (December 2006) US\$, July 2004-September 2018

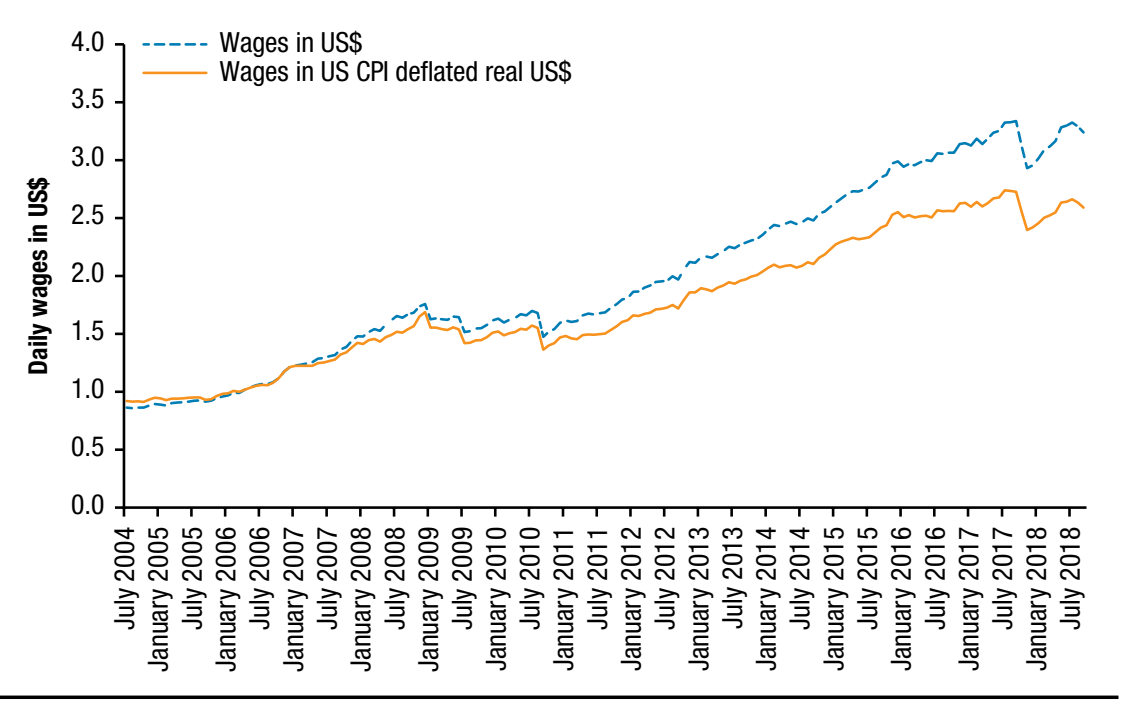

Source: Authors' computation using CSA nominal wages data (Ethiopia, CSA 2018a), National Bank of Ethiopia (2018), and US Bureau of Labor Statistics (2018).

October 2017. This might have been linked to the rapid devaluation of the birr in those periods (World Bank 2014).

To improve our assessment of local wage and price situations and to evaluate changes in the purchasing power of agricultural wage labor, we study real wages of unskilled laborers obtained by deflating nominal wages using both the regional average General CPI (GCPI) and the Poor Person's General CPI.

In Figure 11.7 we present urban and rural wages deflated by the General CPI. We note significant increases in real wages during the period: GCPI deflated real wages of unskilled labor in rural areas increased from $27.3 \mathrm{birr}$ in the third quarter of 2004 to 45.3 birr in the third quarter of 2018 (total growth of 69 percent), while in urban areas it increased from 28.4 birr to 48.4 birr (total growth of 70 percent). Generally, the urban-rural wage gap has been low during most of the period. Wages in urban areas were on average 6 percent higher. This wage gap is significantly lower than those noted in other countries-for example, in Bangladesh real urban wages were double those of rural wages at the end of the 1990s but the gap gradually declined to 25 percent in 2012 (Zhang et al. 2014; Yang et al. 2013). However, the wage gap has been widening in recent years. 
FIGURE 11.7 Regional General CPI (GCPI) deflated daily wages of unskilled laborers in rural and urban areas in Ethiopia, in December 2011 birr per day, July 2004-September 2018

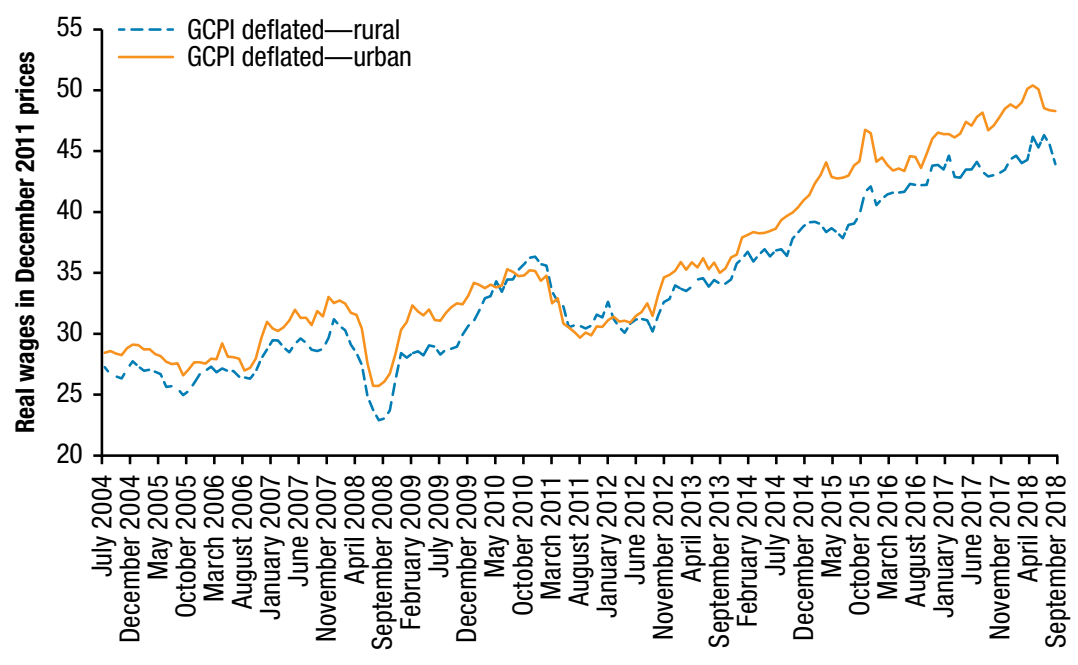

Source: Authors' computation using CSA nominal wages data (Ethiopia, CSA 2018a) and CSA regional GCPI data (Ethiopia, CSA 2018b).

In Figure 11.8 we provide the Poor Persons' General CPI (PP-GCPI) deflated daily real wages of unskilled labor. ${ }^{8}$ PP-GCPI deflated average real wages of unskilled labor were 29.3 birr in rural areas and 31.3 birr in urban areas in the third quarter of 2004. This increased by an average of nearly 18.4 birr and 17.2 birr in the second quarter (that is, April-June) of 2017, or by about 3.9 percent and 3.5 percent per year in rural and urban areas, respectively. Similar to GCPI deflated wages, the PP-GCPI deflated urban-rural real wage gap was higher during 2008 and 2009, during which it averaged 11 percent, whereas the wage gap has been 3.4 percent during the rest of the period. Growth in PP-GCPI deflated real wages were mostly similar to the growth pattern in GCPI deflated real wages, indicating significant welfare improvements for such labor over time. However, the difference in PP-GCPI deflated real wage levels between urban and rural areas have in recent periods become smaller, indicating higher prices of goods for consumption in urban areas. We note a significant decline in real wages during 2008 and between

8 PP-GCPI could not be computed for the period after June 2017 because expenditure shares of the 26 food and nonfood categories have changed and data on the new shares are currently unavailable. 
FIGURE 11.8 Poor Persons' General CPI (PP-GCPI) deflated daily wages of unskilled laborers in rural and urban areas in Ethiopia, in December 2011 birr per day, July 2004-June 2017

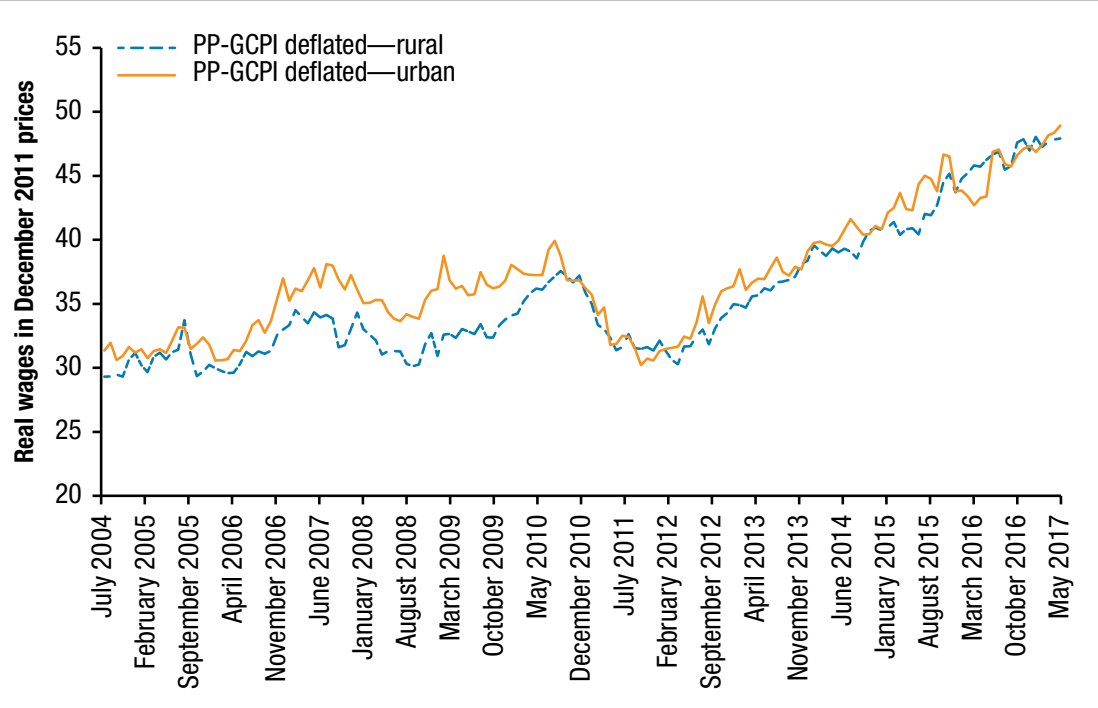

Source: Authors' computation using nominal wages data from CSA (Ethiopia, CSA 2018a).

the middle of 2010 and 2011, when inflation rates in the country were high and wage adjustments were significantly lower (Headey et al. 2012).

\section{Drivers of Change in Wage Levels for Unskilled Labor}

The Ethiopian economy has shown significant growth over the past decadegrowth in real gross domestic product (GDP) averaged 11 percent during the 2004-2013 period (World Bank 2015a). We investigate whether real wages of unskilled labor in rural areas were impacted by this growth in the overall and sectoral GDP. For this purpose we use the World Development Indicators data (World Bank 2018) on real (aggregate) GDP and real value-added in agriculture, manufacturing and industry, and services, together with PP-GCPI deflated real wages. In these analyses we use national averaged real wage as dependent variable, and we interchangeably use nationally aggregated real GDP and real value-added in agriculture, manufacturing and industry, and services as explanatory variables.

Results of the econometric analyses are shown in Table 11.10. Each of the entries in the table are obtained by regressing the explanatory variables listed in the first column on average annual PP-GCPI deflated real wages of rural areas. We categorize zones as rural using the four criteria defined in the first 
TABLE 11.10 Estimates of growth-unskilled real wage elasticity for rural populations in Ethiopia between 1999 and 2014 using different definitions of rural areas, by economic sector

Dependent variable (real wages in rural areas where rural areas are defined as)

\begin{tabular}{lcccc} 
Explanatory variable & $\begin{array}{c}\text { Average woreda } \\
\text { population in zone } \\
\text { less than } 30,000\end{array}$ & $\begin{array}{c}\text { Average woreda } \\
\text { population in zone } \\
\text { less than } 50,000\end{array}$ & $\begin{array}{c}\text { Rural } \\
\text { areas }^{\mathrm{a}}\end{array}$ & $\begin{array}{c}\text { Nonurban } \\
\text { regions }^{\mathrm{b}}\end{array}$ \\
\hline Real GDP & $0.22^{\star \star \star}$ & $0.18^{\star \star \star}$ & $0.15^{\star \star \star}$ & $0.12^{\star \star \star}$ \\
Real agricultural GDP & $0.24^{\star \star \star}$ & $0.20^{\star \star \star}$ & $0.17^{\star \star \star}$ & $0.15^{\star \star \star}$ \\
Real manufacturing GDP & $0.19^{\star \star \star}$ & $0.16^{\star \star \star}$ & $0.14^{\star \star \star}$ & $0.12^{\star \star \star}$ \\
Real industry GDP & $0.17^{\star \star \star}$ & $0.14^{\star \star \star}$ & $0.12^{\star \star \star}$ & $0.10^{\star \star \star}$ \\
Real services GDP & $0.15^{\star \star \star}$ & $0.12^{\star \star \star}$ & $0.11^{\star \star \star}$ & $0.09^{\star \star \star}$ \\
\hline
\end{tabular}

Source: Authors' analysis using Ethiopia, CSA (2018a), Ethiopia, CSA (2007), and World Bank (2015b).

Note: Coefficients with superscripts ${ }^{\star \star \star},{ }^{\star \star}$, and * are significant at 1 percent, 5 percent, and 10 percent levels, respectively. GDP = gross domestic product.

a. Woredas other than those that comprise the urban centers of Addis Ababa, Harari, or Dire Dawa regions or the cities of Mekele, Gondar, Bahir Dar, Dessie, Adama, Bishoftu, Kersa, Jigjiga, and Hawassa.

b. Regions other than Addis Ababa, Harari, or Dire Dawa.

row of the table. The data cover the 1999-2014 period, and each of the analyses comprise 16 observations. The results in Table 11.10 indicate that real wages in rural areas increase at 22 percent of the increase in aggregate GDP in rural administrative zones where zones are defined as rural if an average woreda in the zone has a population of fewer than 30,000. For the remaining three criteria used to define rural zones, the elasticity of real wages with respect to GDP is generally lower, ranging from 12 percent to 18 percent. The results indicate that the elasticity of rural real wages with respect to real agriculture sector value-added (GDP) was 24 percent in predominantly rural areas with woredas averaging fewer than 30,000 . The elasticity ranged between 15 percent and 20 percent when this relationship was computed including more zones with larger populations. The elasticity of wages with respect to manufacturing, industry, and services were 19 percent, 17 percent, and 15 percent, respectively, in predominantly rural zones, with the elasticity being lower in zones with larger populations.

Two observations are notable about these results. First, the elasticity of real wages is highest with respect to agricultural value-added. This is likely because of the large importance of agriculture in most of the zones considered. Second, despite the value-added in agriculture accounting for less than 50 percent of the GDP during the period analyzed, the elasticity of real rural wages with respect to aggregate GDP is close but less than the elasticity of agricultural GDP, particularly in predominantly rural areas. The latter means that wages 
in rural areas respond most to changes in output that is locally produced, seemingly as most of the local population is engaged in these activities.

\section{Implications of Wage Changes}

Here we point to some of the likely implications of trends in rural wages and patterns in agricultural labor use observed in the sections above. In particular, we discuss the link between agricultural wages and rural poverty on the one hand and adjustments in agricultural production practices, such as laborsaving modern inputs, agricultural mechanization, and increase in the likelihood of using of modern inputs due to alleviated seasonal liquidity constraints on the other hand.

First, an important implication of the transformation of rural and agricultural labor markets is its role in poverty reduction (Ravallion 2000). We investigate this effect using Figure 11.9, which plots a quadratic function of the predicted Poverty Head Count index against real wages, both of which are zonally aggregated and pertain to the years 1996, 2000, 2005, and 2011. The figure demonstrates that increases in real wages are strongly correlated with a decline in poverty. This negative relationship is particularly strong at lower real wages. Similar patterns have been observed in other settings (for example, Ravallion 2000).

We use the same data to econometrically test whether zonal-level poverty HCI is related with real wages levels following Lanjouw and Murgai (2009). The general equation we estimate is given as:

$$
\text { In Poverty } H C I_{j, t}=\beta_{0}+\beta_{1} \text { In Real wage } e_{j, t}+\eta_{j}+\tau+e_{j, t}
$$

where Poverty $H C I_{j, t}$ stands for poverty HCI of zone $j$, such that $j \in[1,2, \ldots, 56]$ in year $t$, with $\in[1996,2000,2005,2011], \eta_{j}$ represents fixed effects of zone $j$; and $\tau$ stands for a time trend variable. We estimate OLS and fixed-effects specifications of equation (1) whereby in the OLS specification the zone fixed-effect variables $\left(\eta_{j}\right)$ are replaced by region dummies. We provide results of the analyses in Table 11.11.

The results indicate that the elasticity of poverty $\mathrm{HCI}$ with respect to real wages is negative and significant in both specifications. Moreover, the elasticities from the OLS $(-0.57)$ and fixed-effects $(-0.44)$ specifications are close to each other. Elasticities obtained from specifications without time trends (not shown) are unit elastic in both models.

Second, we note increasing substitution of labor with labor-saving modern inputs such as herbicides over time in Ethiopia (Bachewe et al. 2015; Minten et al. 2013). This is partly driven by an increase of real wages, as documented 
FIGURE 11.9 Correlation of prevailing real wages and Poverty Head Count Index by administrative zone in Ethiopia

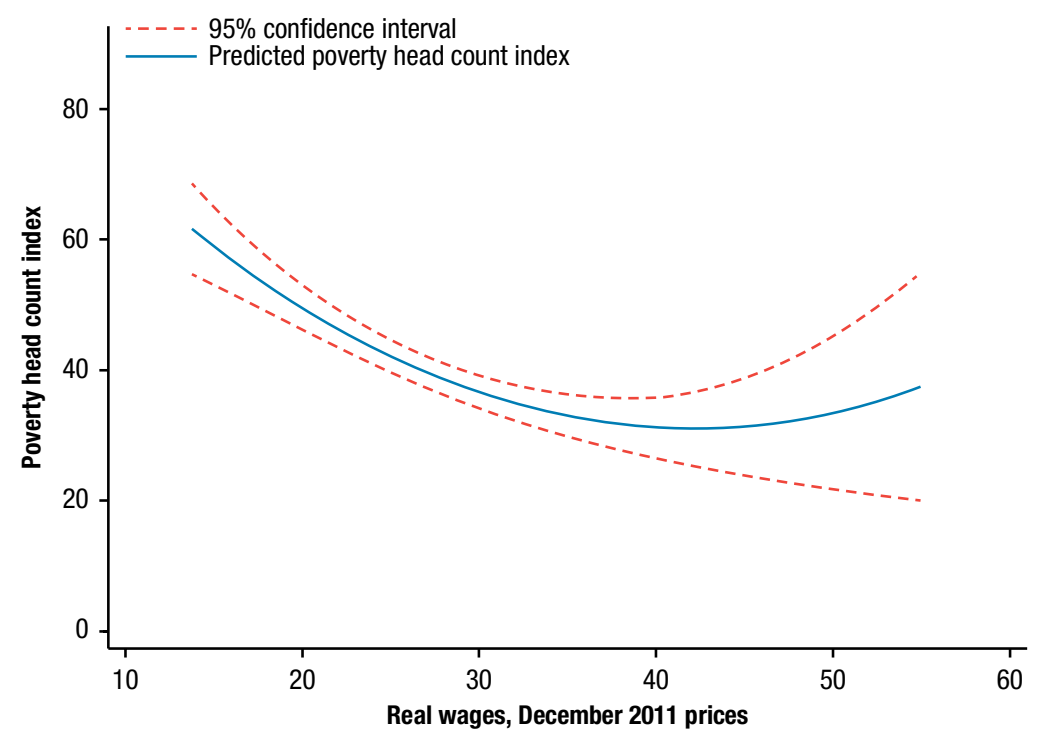

Source: Authors' computations using Ethiopia, CSA (2014a; 2014b); Hill and Tsehaye (2018).

TABLE 11.11 Strength of the association between zonal-level poverty head count index and real wages in Ethiopia

Dependent variable: Zonal poverty head count index in 1996, 2000, 2005, and 2011

\begin{tabular}{lcc}
\hline Variables & OLS & $\begin{array}{c}\text { Fixed } \\
\text { effects }\end{array}$ \\
\hline Log of real wages & $-0.574^{\star \star \star}$ & $-0.444^{\star}$ \\
Time trend & $(0.179)$ & $(0.229)$ \\
& $-0.141^{\star \star \star}$ & $-0.149^{\star \star \star}$ \\
Constant & $(0.031)$ & $(0.033)$ \\
& $6.027^{\star \star \star}$ & $5.288^{\star \star \star}$ \\
\hline Fstatistics & $(0.615)$ & $(0.719)$ \\
Probability of $F$ & 8.4 & 28.5 \\
\hline
\end{tabular}

Source: Authors' analysis using Ethiopia, CSA (2014a; 2014b) and Hill and Tsehaye (2018). Coefficients with superscripts ${ }^{\star \star *},{ }^{\star \star}$, and ${ }^{*}$ are significant at 1 percent, 5 percent, and 10 percent levels, respectively. 
above, as well as by a decrease of real prices for herbicides (Tamru et al. 2017). Figure 11.10 shows that when herbicides are used, the weeding efforts are significantly lower, indicating substitution between these inputs. The tightening of the labor markets might contribute to the increasing use of herbicides in the country. For example, Figure 11.10 shows the increasing adoption of herbicides in major commercial teff areas in the country: 31 percent of the teff farmers used herbicides 10 years prior to the survey, but this figure increased to 63 percent in 2012. Commercially oriented and well-connected farming areas show a particularly strong uptake of such herbicides, possibly linked to the higher wages that are paid in such areas.

Third, higher rural wages often provide incentives for mechanization in agriculture (Binswanger 1986; Diao et al. 2014; Yang et al. 2013). Most surveys in Ethiopia do not collect data on mechanization, so we cannot assess the extent to which mechanization is used in different parts of the agricultural production process. In a rare exception, Berhane, Hirvonen, and Minten (2015) analyze the use of mechanized services in major production zones in the country. They find that about 9 percent of smallholder farmers used mechanized services at some period during the agricultural season, mostly for plowing $(5$ percent) and relatively less for harvesting ( 3 percent) and threshing ( 2 percent). While the adoption of these mechanized services is still relatively low, Berhane, Hirvonen, and Minten (2015) show a strong threshold effect in the use of mechanized services and the reported daily wages in the community (Figure 11.11). While a slight upward trend is seen in the use of mechanization by smallholders for wage levels up to 100 birr per day (just over US $\$ 5$ ), use of mechanized services significantly expand after that wage threshold. Yang et al. (2003) have found similar strong effects of wage increases on the adoption of mechanization in agriculture in China. Unfortunately we do not have data on the cost of mechanization services over time in Ethiopia, and therefore we cannot compare to what extent possible price changes for these services might have been driving increasing adoption.

Fourth, as shown in other studies, off-farm income might lead to a relaxation of credit constraints in the period of the cropping season when agricultural inputs are required and therefore might lead to improved agronomic practices. Reardon, Crawford, and Kelly (1994) and Lamb (2003) show that such off-farm income sources might lead to significant farm investments and higher use of modern inputs, leading to higher agricultural productivity. We use the AGP baseline dataset to test the extent to which households that have off-farm income in Ethiopia are more likely to use modern inputs, such as fertilizer, improved seeds, and agrochemicals. We find that only in the case of 
FIGURE 11.10 Association between use of weeding labor and value of herbicides used (left); prevalence of herbicide use by teff producers in $\mathbf{2 0 0 2}$ and 2012 as a function of transport costs to Addis Ababa (right)

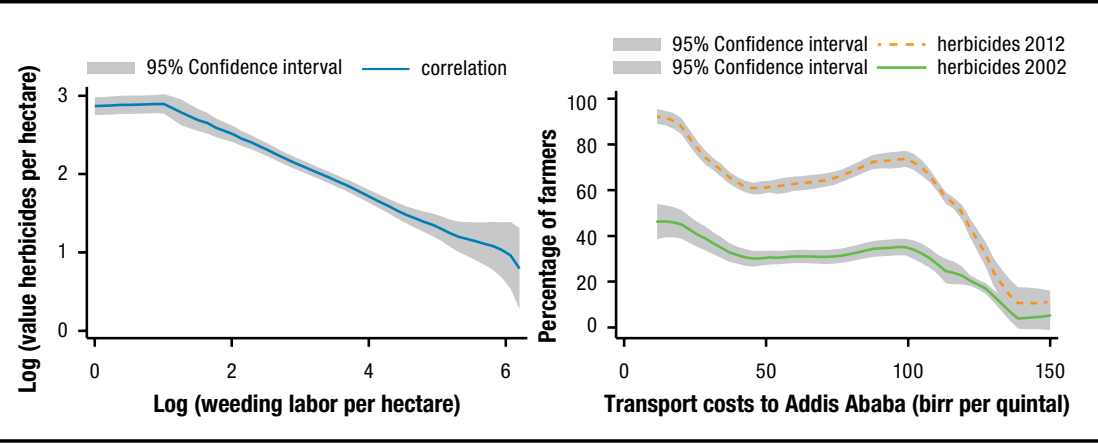

Source: Authors' computations using IFPRI and EDRI (2020).

FIGURE 11.11 Prevalence of use of agricultural mechanization and prevailing daily agricultural wage rates in Ethiopia

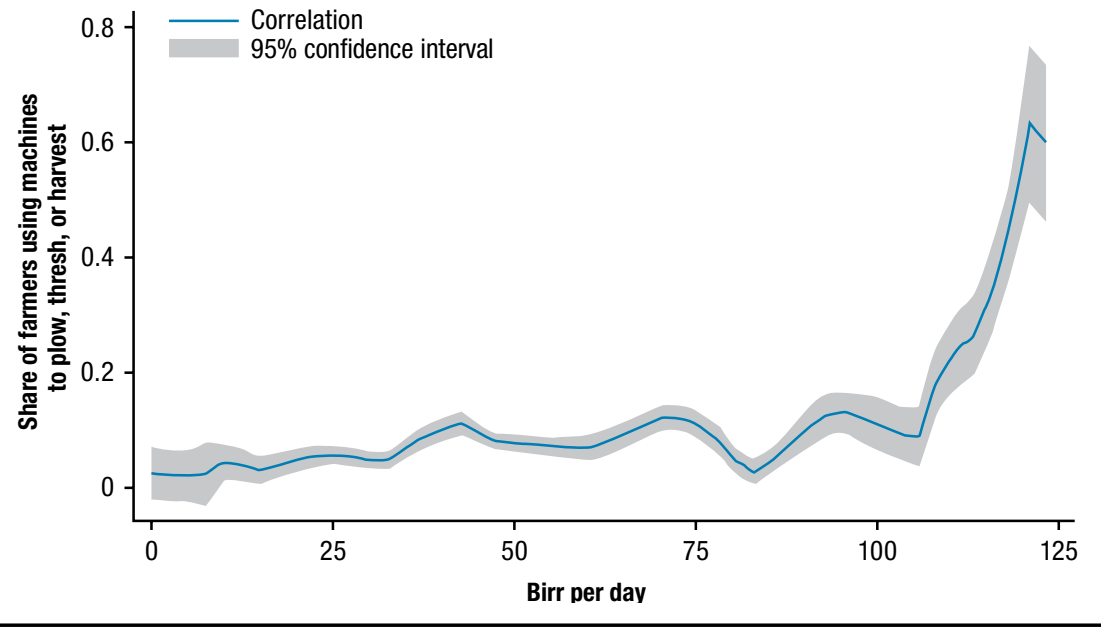

Source: Berhane, Hirvonen, and Minten (2015), citing data from FtF (2015).

Note: Local polynomial regression. 
chemical fertilizer use is off-farm income positively associated with a higher likelihood of using chemical fertilizer. However, the association is weak, as the coefficient is only significant at the 10 percent level.

\section{Conclusion}

As economies develop and shift away from agrarian subsistence to commercial agriculture and increasingly to nonagriculture-based economic activities, labor markets emerge and increasingly become a critical part of the economy in providing livelihoods for many people (Fox et al. 2013). In the initial stages of this transformation, and especially so in rural areas, these labor markets are important for poverty reduction as well as for assuring employment for the rural youth, an increasing concern in Africa, given its rapidly growing population and its "youth bulge." In the case of Ethiopia, the economy is undergoing rapid transformation, mostly driven by rapid agricultural growth. However, priorities are shifting in the planning process, and there is increasing emphasis on stimulating the manufacturing sector as an anticipated source of growth in future decades. This is illustrated in the second phase of the Ethiopian government's Growth and Transformation Plan. Given that such shifts will have important implications on labor markets, it is important to understand rural and agricultural labor markets. This chapter aims to fill this knowledge gap and contributes to greater insight into understanding likely future trends in these markets.

We find that off-farm income in the high-potential agricultural areas in Ethiopia where the AGP is being implemented makes up almost 18 percent of household income and that wage labor income accounts for 10 percent. Wage income is estimated to be as important as livestock income in these areas. We estimate that in these high-potential agricultural zones of the country, only 7 percent of the agricultural production is carried out by hired labor. We find that there is considerable heterogeneity in rural unskilled labor markets over space and time. Agricultural labor markets are relatively more important in better connected areas and in urban areas, which is reflected in higher wages in these areas. This suggests that connectedness and urbanization are among the driving forces toward improved labor markets.

Moreover, we note strong seasonality with peaks in hired labor use and wages in the harvest period. Income from off-farm sources are shown to be relatively more important for the poor than for the rich, suggesting that push factors might still be relatively more important in rural areas for engagement by households in the rural off-farm income sector than are pull factors. While 
wages of unskilled labor in rural areas of Ethiopia are still low relative to the international context, real wages are on the rise, measured both in US dollars and birr. This is seemingly driven by an improvement in agricultural performance, which leads to a reduction in poverty. This increase in real wages is gradually leading to an increasing push toward the adoption of labor-saving technologies in agriculture, such as mechanized services-though starting from a low base-as well as to a widespread use of herbicides that save on weeding labor.

These findings have important implications on policy. First, low wages have been an asset for attracting investors to Ethiopia, and they have contributed to the success of investments in labor-intensive industries, such as in floriculture. However, our results indicate that Ethiopia may gradually lose that edge before it further matures as the wage gap between rural and urban areas narrows and future cheap labor sources disappear. Ethiopia therefore needs to make sure that the skills of its young population are upgraded so that industries can develop in those areas where labor productivity is higher. Second, the higher costs of labor as well as the increasing commercialization of agriculture will require increasing adoption of labor-saving technologies in the sector. It is therefore important that Ethiopia proactively implements policies that allow for the provision of such appropriate technologies at low cost. Third, flexible and responsive labor markets require easier migration to those areas with employment opportunities. Therefore migration needs to be encouraged through more flexible land tenure and more secure land rental rules. Such policies could also facilitate the consolidation of small farms, given the introduction of labor-saving technologies. Furthermore, this may subsequently reduce the incentives to operate small farms, which have the traditional advantages over larger farms of decreased costs of labor supervision.

\section{References}

Bachewe, F., G. Berhane, B. Minten, and A. S. Taffesse. 2015. Agricultural Growth in Ethiopia (2004-2014): Evidence and Drivers. IFPRI-ESSP Working Paper 81. Addis Ababa: International Food Policy Research Institute/Ethiopia Strategy Support Program (IFPRI/ ESSP).

Berhane, G., M. Dereje, J. Hoddinott, B. Koru, F. Nisrane, F. Tadesse, A. S. Taffesse, I. Worku, and Y. Yohannes. 2013. Agricultural Growth Program (AGP) of Ethiopia-Baseline Report 2011. ESSP-EDRI Report. Addis Ababa: IFPRI. 
Berhane, G., K. Hirvonen, and B. Minten. 2015. Mechanization of Agriculture in Ethiopia: Evidence from the 2015 Feed the Future Survey. IFPRI-ESSP II Research Note 41. Addis Ababa: IFPRI/ ESSP II.

Binswanger, H. 1986. “Agricultural Mechanization: A Comparative Historical Perspective.” World Bank Research Observer 1 (1): 27-56.

Block, S., and P. Webb. 2001. “The Dynamics of Livelihood Diversification in Post-Famine Ethiopia." Food Policy 26 (4): 333-350.

Deichmann, U., F. Shilpi, and R. Vakis. 2009. “Urban Proximity, Agricultural Potential and Rural Non-Farm Employment: Evidence from Bangladesh." World Development 37 (3): $645-660$.

Dercon, S., and P. Krishnan. 1996. "Income Portfolios in Rural Ethiopia and Tanzania: Choices and Constraints." Journal of Development Studies 32 (6): 850-875.

Diao, X., F. Cossar, N. Houssou, and S. Kolavalli. 2014. "Mechanization in Ghana: Emerging Demand and the Search for Alternative Supply Models." Food Policy 48: 168-181.

Escobal, J. 2001. “The Determinants of Nonfarm Income Diversification in Rural Peru." World Development 29 (3): 497-508.

Ethiopia, CSA (Central Statistical Agency). 2007. Household Income, Consumption and Expenditure (HICE) Survey 2004/05. Volumes 1 and 2. Statistical Bulletin 394. Addis Ababa.

- 2011. Unpublished Baseline Survey data. Addis Ababa, Ethiopia: The Agricultural Growth Program of Ethiopia.

-2013. Unpublished Ethiopia Rural Socioeconomic Survey (ERSS) data. Addis Ababa, Ethiopia: Central Statistical Agency.

—. 2014. Population Projection of Ethiopia for All Regions at Wereda Level from 2014-2017. Addis Ababa.

-2018a. Consumer Price Survey. Addis Ababa.

- 2018b. Country and Regional Level Consumer Price Indices. Addis Ababa.

Fafchamps, M., and F. Shilpi. 2003. "The Spatial Division of Labour in Nepal." Journal of Development Studies 39 (6): 23-66.

_. 2005. "Cities and Specialisation: Evidence from South Asia." Economic Journal 115 (503): 477-504.

Fox, L., C. Haines, J. H. Munoz, and A. Thomas. 2013. Africa's Got Work to Do: Employment Prospects in the New Century. IMF Working Paper WP/13/201. Washington, DC: International Monetary Fund. 
FtF (Feed the Future). 2013. Unpublished Ethiopia Feed the Future Survey data.

- 2015. Unpublished Impact Evaluation Survey data. Addis Ababa, Ethiopia.

Haggblade, S., P. B. Hazell, and T. Reardon. 2007. Transforming the Rural Nonfarm Economy: Opportunities and Threats in the Developing World. Baltimore: Johns Hopkins University Press.

Headey, D., F. N. Bachewe, I. Worku, M. Dereje, and A. S. Taffesse. 2012. Urban Wage Behavior and Food Price Inflation: The Case of Ethiopia. IFPRI-ESSP Working Paper 41. Addis Ababa: IFPRI/ESSP.

Hill, R., and E. Tsehaye. 2018. Growth, Safety Nets and Poverty: Assessing Progress in Ethiopia from 1996 to 2011. Policy Research working paper; no. WPS 8380. Washington, DC: World Bank Group.

Holden, S., B. Shiferaw, and J. Pender. 2004. "Non-farm Income, Household Welfare, and Sustainable Land Management in a Less-Favoured Area in the Ethiopian Highlands." Food Policy 29 (4): 369-392.

IFPRI (International Food Policy Research Institute) and EDRI (Ethiopian Development Research Institute). 2019. Coffee Value Chain Survey in Ethiopia: Producer/Household Survey. Washington, DC: IFPRI [dataset]. https://doi.org/10.7910/DVN/GRIAV8. Harvard Dataverse, VERSION 1.

- 2020. Teff Value Chain in Ethiopia: Producer/Household Survey. Washington, DC: IFPRI [dataset]. https://doi.org/10.7910/DVN/NLT2MO, Harvard Dataverse, V1.

Jacoby, H., and B. Minten. 2009. “On Measuring the Benefits of Lower Transport Costs.” Journal of Development Economics 89 (1): 28-38.

Lamb, R. L. 2003. "Fertilizer Use, Risk, and Off-Farm Labor Markets in the Semi-Arid Tropics of India." American Journal of Agricultural Economics 85 (2): 359-371.

Lanjouw, J. O., and P. Lanjouw. 2001. “The Rural Non-Farm Sector: Issues and Evidence from Developing Countries." Agricultural Economics 26 (1): 1-23.

Lanjouw, P., and R. Murgai. 2009. "Poverty Decline, Agricultural Wages, and Nonfarm Employment in Rural India: 1983-2004." Agricultural Economics 40: 243-263.

Minten, B., S. Tamru, E. Engida, and T. Kuma. 2013. Ethiopia's Value Chains on the Move: The Case of Teff. IFPRI-ESSP Working Paper 52. Addis Ababa: IFPRI/ESSP II.

National Bank of Ethiopia. 2018. Daily Exchange Rate. Accessed December 1, 2018. https:// nbebank.com/inter-bank-daily-foreign-exchange-rate-in-usd/.

Otsuka, K., Y. Liu, and F. Yamauchi. 2014. The Future of Small Farms in Asia. Accessed February 19, 2016. www3.grips.ac.jp/ esp/wp-content/uploads/2014/11/112014.pdf. 
Ravallion, M. 2000. "Prices, Wages and Poverty in Rural India: What Lessons Do the Time Series Data Hold for Policy?" Food Policy 25 (3): 351-364.

Reardon, T., J. Berdegué, C. Barrett, and K. Stamoulis. 2006. "Household Income Diversification into Rural Nonfarm Activities." In Transforming the Rural Nonfarm Economy, edited by S. Haggblade, P. Hazell, and T. Reardon, 115-140. Baltimore: Johns Hopkins University Press.

Reardon, T., E. Crawford, and V. Kelly. 1994. "Links between Nonfarm Income and Farm Investment in African Households: Adding the Capital Market Perspective." American Journal of Agricultural Economics 76 (5): 1172-1176.

Tamru, S., B. Minten, F. Bachewe, and D. Alemu. 2017. “The Rapid Expansion of Herbicide Use in Smallholder Agriculture in Ethiopia: Patterns, Drivers, and Implications." European Journal of Development Research 29 (3): 628-647.

United States, Bureau of Labor Statistics. 2018. Historical Consumer Price Index Data. Accessed December 1, 2018. www.bls.gov/cpi/home.htm.

USAID (United States Agency for International Development). 2011. "Feed-the-Future Ethiopia: Multi-year Strategy (2011-2015).” Accessed February 9, 2016. www.usaid.gov/sites/default/ files/documents/1860/USAID\%20FtF\%20MYS\%20Final\%20Version.pdf.

Wiggins, S., and S. Keats. 2014. Rural Wages in Asia. London: Overseas Development Institute.

World Bank. 2014. Ethiopia: Poverty Assessment. Report No. AUS6744. Poverty Global Practice. Africa Region. World Bank Group. Washington, DC.

- 2015a. Ethiopia's Great Run: The Growth Acceleration and How to Pace It. Report no. 99399-ET. Washington, DC.

—.2015b. World Development Indicators. Accessed October 15, 2015. http://data.worldbank .org/data-catalog/world-development-indicators.

Yang, J., Z. Huang, X. Zhang, and T. Reardon. 2013. “The Rapid Rise of Cross-Regional Agricultural Mechanization Services in China.” American Journal of Agricultural Economics 95 (5): 1245-1251.

Zhang, X., S. Rashid, K. Ahmad, and A. Ahmed. 2014. "Escalation of Real Wages in Bangladesh: Is It the Beginning of Structural Transformation?” World Development 64: 273-285. 
